\section{SOI: $1.1 /$ TAS
International
Scientific Journal Theoretical \& Applied Science}

\author{
Ameneh Amiri \\ MA in Educational Psychology, Education, \\ nikshhr, sistan\&balouchestan, Iran
}

p-ISSN: 2308-4944 (print) e-ISSN: 2409-0085 (online)

Year: $2018 \quad$ Issue: $03 \quad$ Volume: 59

Salim Balouch

MA in Educational administration, Education, nikshhr,sistan\&balouchestan, Iran

Published: $14.03 .2018 \quad \underline{\text { http://T-Science.org }}$

SECTION 24. Sociological research.

\title{
RELATIONSHIP OF SOCIAL DESIRABILITY AND SPIRITUAL INTELLIGENCE TO ACADEMIC ACHIEVEMENT OF STUDENTS (CASE STUDY OF SECOND-GRADE HIGH SCHOOL STUDENTS IN NIKSHAHR COUNTY)
}

\begin{abstract}
The purpose of this study was to investigate the relationship between social desirability, spiritual intelligence and academic achievement of second-grade high school students in Nikshaher City. The research method was descriptive correlational. The study population consisted of all second-grade high school students who are studying at school during 2017-2018. The statistical sample was selected using simple random sampling (315 students). The data were analyzed both at descriptive and inferential levels. Stöber's social desirability questionnaire with 0.90 reliability was used for examining social desirability, King's Spiritual Intelligence questionnaire with 0.86 reliability for spiritual intelligence, and for measure of students' academic achievement their grade point average (GPA) in the first semester was used. Research findings indicate that social desirability is associated with Critical Existential Thinking, Personal Meaning Production, Transcendental Awareness, Conscious State Expansion and total spiritual intelligence. Similarly, academic achievement is associated with Critical Existential Thinking, Personal Meaning Production, Transcendental Awareness, Conscious State Expansion and total spiritual intelligence. There is also a relationship between social desirability and academic achievement. Among the constructs of spiritual intelligence, critical existential thinking and transcendental awareness have better predictability of social desirability among students.

Key words: social desirability, spiritual intelligence, academic achievement

Language: English

Citation: Amiri A, Balouch S (2018) RELATIONSHIP OF SOCIAL DESIRABILITY AND SPIRITUAL INTELLIGENCE TO ACADEMIC ACHIEVEMENT OF STUDENTS (CASE STUDY OF SECOND-GRADE HIGH SCHOOL STUDENTS IN NIKSHAHR COUNTY). ISJ Theoretical \& Applied Science, 03 (59): 86-92. Soi: http://s-o-i.org/1.1/TAS-03-59-13 Doi: crostef https://dx.doi.org/10.15863/TAS.2018.03.59.13
\end{abstract}

\section{Introduction}

Academic achievement is actually an effort at success and victory, and a major indicator of education measurement and quality. That is, in order to achieve this goal, whether student has received sufficient learning and made a breakthrough, we aim to measure their academic achievement in the learning [1]. there are many factors affecting student's academic achievement, some of which are cognitive and some non-cognitive factors [2]. One of these variables that probably affects student's academic achievement is social desirability. Social desirability is individuals' desire for responding favorably and socially rather than describing what they really think, believe or do [3]. Similarly, it has been established that intelligence also affects academic achievement, in the sense that it includes different kinds, one of which is spiritual intelligence.
As individual's underlying beliefs, spiritual intelligence makes a great contribution to different areas. Spiritual intelligence, i.e. SQ, can be known as an ability which enables us to achieve dreams. This intelligence underlies everything that we believe and encompasses the role of beliefs, norms, values in activities that we undertake [4]. King proposes four constructs of spiritual intelligence; critical thinking; the first construct of spiritual intelligence refers to critical existential thinking; the ability to critically contemplate the nature of existence, reality, the universe, space, time, death, and other existential/metaphysical issues; personal meaning production; the second construct of spiritual intelligence refers to production of personal meaning, which is the ability to derive personal meaning and purpose from all physical and mental experiences, including the capacity to create and master a life 
purpose; transcendental awareness; the third construct of spiritual intelligence refers to the capacity to identify transcendent dimension/patterns of the self, others and material world; conscious state expansion; the last construct of spiritual intelligence refers to the ability to enter higher states of consciousness (e.g. pure consciousness, cosmic consciousness, unity, oneness). According to this model, people with high spiritual intelligence are endowed with balanced, ideal and concurrent consideration to the following; God (source of creation), creation (environment), and the self [5]. Academic performance is one of the acceptance factors in school and classroom. Similarly, it is important when it comes to finding a job and promoting to its different ranks. Since every education system is often being assessed by experts in an attempt to achieve the best conditions and results and address shortcomings in the entire educational processes and optimally use inputs, and eventual the product of the educational system is graduates with certain qualifications. Academic performance can serve as the best and most objective criteria for examining and evaluating the efficiency of educational systems.

[6] indicated that spiritual intelligence predicts $83 \%$ of social desirability. Moreover, the results of Pearson correlation coefficient showed that there is a significant and positive relationship between spiritual intelligence and social desirability. Findings demonstrated that the more individuals' spiritual intelligence, the easier their social relationships will be confirmed. [7] demonstrated that there is no significant relationship between social desirability and students' academic achievement. [8] indicated that there is a significant relationship between spiritual intelligence and academic achievement of male and female primary school students in Urumia. [9] indicated that spiritual intelligence is significantly associated with academic performance and academic achievement, and spiritual life and understanding with the source of being (construct of spiritual intelligence) is able to predict academic performance and academic achievement. [10] showed that $83 \%$ of students were regarded as a successful group in comparison with the group with academic failure. Their mean score of spiritual intelligence was slightly higher, but there was no significant difference between both groups, as academic achievement was linked with dimensions of spiritual intelligence based on their GPA; however, the score of progress motivation was not significantly linked with spiritual intelligence. [11] demonstrated that promotion of spiritual intelligence can build up a happy spirit and academic achievement among students of medical sciences, and hence improvement of patients' healthcare quality. [12] showed that about $12 \%$ of variance of intelligent students' academic achievement can be predicted by variables like social desirability, mental health, and selfefficacy, while it was estimated to be about $31 \%$ among normal students. The results show that high level of social desirability and higher levels of mental health and self-efficacy can build up academic achievement. [13] found that there is a positive and significant relationship between emotional intelligence and spiritual intelligence. Similarly, the results revealed that the scores of students with higher emotional and spiritual intelligence are higher than those of other students[14]found the positive and significant relationship between emotional and spiritual intelligence and academic achievement of students. Moreover, the results showed that promotion and growth of spiritual and emotional intelligence can increase progress in students' education[15] in their study entitled "spiritual intelligence and self-efficacy beliefs in prediction of high school students' academic achievement", concluded that age, gender and self-efficacy are positive predictors of academic achievement. Additionally, the results showed that scores of females' academic achievement are higher than those of males', but the relationship was not significant. In his study titled "social desirability and understanding of competency and its relation to academic achievement; gender and ethnicity", [16] concluded that there is no significant difference between gender and ethnicity when it comes to social desirability. In addition to this, regression analysis showed that mastery of English language was the only variable which significantly made a difference to academic achievement.

Therefore, considering the special importance that education has to comprehensive development and it is a factor associated with educational system and can affect it, academic achievement is studied in this work, in that an attempt is made to investigate it and its relation to spiritual intelligence and social desirability among students of Nikshahr County.

\section{Materials and methods}

The present research is an applied research and it is a descriptive-correlational study by the nature of the subject and the objectives of the study, The statistical population consists of all second-grade school students in the academic year 2017-2018. The sample size was chosen to be 315 students using Morgan's table and stratified random sampling method. Stöber's (2001) Social Desirability scale was used for measuring social desirability, King's (2008) Spiritual Intelligence questionnaire (SISRI) for spiritual intelligence, and for measure of students' academic achievement their grade point average (GPA) in the previous semester was used. To measure the validity of Social Desirability questionnaire and Spiritual Intelligence, these questionnaires were presented to university professors so that they could comment on the 


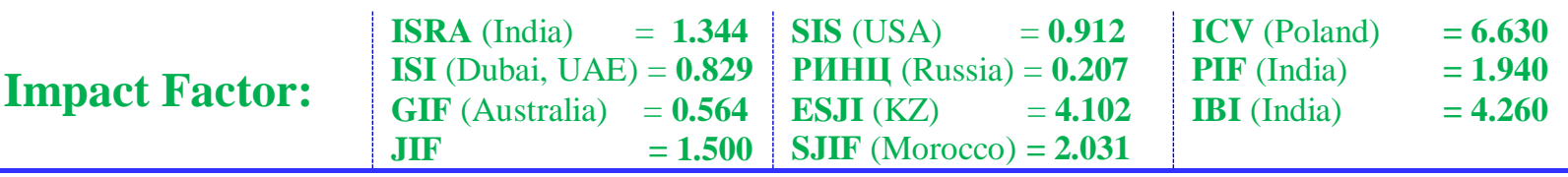

proportion of items and constructs to scales. The social desirability questionnaire contained 16 items, and the spiritual intelligence questionnaire contained 24 items. By using Cronbach's alpha, the reliability of the questionnaires was estimated to be 90 for social desirability and 0.86 for spiritual intelligence, respectively. The data were also analyzed by using Pearson correlation coefficient and multivariate regression with SPSS (21st edition).

\section{Results}

Of total respondents (315), a number of 170 $(0.54 \%)$ respondents were male and $145(0.46 \%)$ were female. Moreover, 42 (13.3) students were 15 years of age and 125 (37.9) students were 16. 69 (21.9) were 17 and 79 (25.1) were 18 years of age.

Mean and standard deviation of respondents in research variables

Table 1

\begin{tabular}{|l|llll|}
\hline Row & Variable & Mean & $\begin{array}{l}\text { Standard } \\
\text { deviation }\end{array}$ & Number \\
\hline 1 & Social desirability & $\mathbf{1 2 . 3 4}$ & $\mathbf{2 . 8 5}$ & $\mathbf{3 1 5}$ \\
\hline $\mathbf{2}$ & Spiritual intelligence & $\mathbf{9 6 . 6 9}$ & $\mathbf{1 8 . 2 7}$ & $\mathbf{3 1 5}$ \\
\hline $\mathbf{3}$ & $\begin{array}{l}\text { Academic } \\
\text { achievement }\end{array}$ & $\mathbf{1 5 . 9 1}$ & $\mathbf{1 . 9 6}$ & $\mathbf{3 1 5}$ \\
\hline
\end{tabular}

As can be seen in table 1 , the highest mean is attributed to spiritual intelligence

Mean and standard deviation of spiritual intelligence constructs

Table 2

\begin{tabular}{|cccc|}
\hline Row & $\begin{array}{c}\text { Constructs of spiritual } \\
\text { intelligence }\end{array}$ & mean & $\begin{array}{c}\text { Standard } \\
\text { deviation }\end{array}$ \\
\hline 1 & Critical existential thinking & $\mathbf{2 7 . 6 1}$ & $\mathbf{5 . 5 3}$ \\
\hline 2 & Personal meaning production & $\mathbf{2 0 . 2 7}$ & $\mathbf{4 . 1 7}$ \\
\hline 3 & Conscious state expansion & $\mathbf{2 8 . 6 5}$ & $\mathbf{5 . 6 7}$ \\
\hline 4 & Transcendental awareness & $\mathbf{2 0 . 1 4}$ & $\mathbf{4 . 0 6}$ \\
\hline
\end{tabular}

Table 2. Shows general information of constructs of spiritual intelligence, the highest mean is attributed to conscious state expansion.
First hypothesis: there is a significant relationship between social desirability and spiritual intelligence of students.

Table 3

Results of Pearson correlation coefficient between social desirability and spiritual intelligence

\begin{tabular}{|c|cc|}
\hline Row & \multicolumn{1}{c}{ Variables } & $\begin{array}{c}\text { Social } \\
\text { desirability }\end{array}$ \\
\hline $\mathbf{1}$ & Critical existential thinking & $0.74 * *$ \\
\hline $\mathbf{2}$ & Personal meaning production & $0.67^{* *}$ \\
\hline $\mathbf{3}$ & Conscious state expansion & $0.72^{* *}$ \\
\hline $\mathbf{4}$ & Transcendental awareness & $0.74 * *$ \\
\hline $\mathbf{5}$ & Total spiritual intelligence & $0.77^{* *}$ \\
\hline
\end{tabular}



tailed).

Correlation is significant at the 0.01 level (2-

The findings of table 3 show that social desirability is linked with critical existential thinking with 0.74 correlation coefficient, with personal meaning production with 0.67 correlation coefficient, with conscious state expansion with 0.72 correlation coefficient, with transcendental awareness with 0.74 correlation coefficient, with total spiritual intelligence with 0.77 correlation coefficient. Therefore, it can be concluded that there is a significant relationship between social desirability and all constructs of spiritual intelligence and total spiritual intelligence of students.

Second hypothesis: there is a significant relationship between spiritual intelligence and academic achievement of students.

Table 4. Results of Pearson correlation coefficient between spiritual intelligence and academic achievement

\begin{tabular}{|ccc|} 
Row & \multicolumn{1}{c}{ variables } & $\begin{array}{c}\text { Academic } \\
\text { achievement }\end{array}$ \\
\hline 1 & Critical existential thinking & $\mathbf{0 . 5 8 * *}$ \\
\hline 2 & Personal meaning production & $\mathbf{0 . 5 2} * *$ \\
\hline 3 & Conscious state expansion & $\mathbf{0 . 5 3} * *$ \\
\hline 4 & Transcendental awareness & $\mathbf{0 . 5 9} * *$ \\
\hline 5 & Total spiritual intelligence & $\mathbf{0 . 6 0} * *$ \\
\hline
\end{tabular}
tailed)

Correlation is significant at the 0.01 level (2-

The findings of table 4 show that academic achievement is linked with critical existential thinking with 0.58 correlation coefficient, with personal meaning production with 0.52 correlation coefficient, with conscious state expansion with 0.53 correlation coefficient, with transcendental awareness with 0.59 correlation coefficient, with total spiritual intelligence with 0.60 correlation coefficient. Therefore, it can be concluded that there is a significant relationship of all constructs of spiritual intelligence and total spiritual intelligence of students to academic achievement of students.

Third hypothesis: there is a significant relationship between social desirability and academic achievement of students.

Table 5

Results of Pearson correlation coefficient between social desirability and academic achievement

\begin{tabular}{|c|c|}
\hline \hline Correlation coefficient & $\begin{array}{r}\text { Social desirability and academic } \\
\text { achievement }\end{array}$ \\
\hline $\mathbf{0 . 6 3}$ & \\
\hline
\end{tabular}

Table 5 shows the results of the correlation between social desirability and academic achievement. As can be seen, the two variables have 0.63 correlation coefficient. Therefore, it can be concluded that there is a significant relationship between social desirability and academic achievement of students.

Fourth hypothesis: constructs of spiritual intelligence are able to predict student's social desirability.

Table 6

A summary of findings of the stepwise regression analysis for prediction of social desirability

\begin{tabular}{|c|c|c|c|c|}
\hline Statistical indicators & $\begin{array}{l}\text { Multiple } \\
\text { correlation } \\
\text { coefficient }\end{array}$ & $\begin{array}{c}\text { Squared } \\
\text { correlation } \\
\text { coefficient }\end{array}$ & $\begin{array}{l}\text { Adjusted } \\
\text { correlation } \\
\text { coefficient }\end{array}$ & $\begin{array}{c}\text { Estimated } \\
\text { standard error }\end{array}$ \\
\hline Critical existential thinking & 0.749 & 0.569 & 0.560 & 1.89 \\
\hline Transcendental awareness & 0.799 & 0.628 & 0.625 & 1.74 \\
\hline
\end{tabular}


According to table 6, correlation coefficients of other constructs of spiritual intelligence were poor and excluded from the regression model. As it can be seen in this table, the constructs critical existential thinking and transcendental awareness have a multiple correlation with social desirability in stepwise regression analysis. By importance, the order of the predictor variables of the stepwise regression analysis in the first step is critical existential thinking by social desirability with 0.749 . In the second step, by adding transcendental awareness, correlation coefficient rose to 0.799 . In total, the two constructs are able to explain 0.628 of social desirability variance, 0.569 of which is attributed to critical existential thinking and 0.05 is attributed to transcendental awareness.

\section{Standard and non-standard regression coefficients for prediction of social desirability}

Table 7

\begin{tabular}{|c|c|c|c|c|c|}
\hline \multirow{2}{*}{$\begin{array}{c}\text { Statistical } \\
\text { indicators }\end{array}$} & \multicolumn{2}{|c|}{ Non-standard coefficient } & \multirow{2}{*}{$\begin{array}{c}\text { Beta } \\
\text { coefficients } \\
\text { of beta }\end{array}$} & T & Significance level \\
\cline { 2 - 5 } constructs & beta & Standard error & - & 3.193 & 0.002 \\
\hline constant & 1.728 & 0.541 & 0.466 & 9.083 & 0.000 \\
\hline $\begin{array}{c}\text { Critical } \\
\text { existential } \\
\text { thinking }\end{array}$ & 0.328 & 0.036 & 0.383 & 7.456 & 0.000 \\
\hline $\begin{array}{c}\text { Transcendental } \\
\text { awareness }\end{array}$ & 0.252 & 0.034 & 0.000 \\
\hline
\end{tabular}

As shown in table 7, in stepwise regression analysis, during the final (second) step, the two constructs namely critical existential thinking and transcendental awareness were entered into the regression equation to predict social desirability. By order, as shown in the table, critical existential thinking with 0.328 beta coefficient and $\mathrm{P}<0.000$ and transcendental awareness with 0.252 and $\mathrm{P}<0.000$ are positively and significantly related to social desirability. The results show that an increase in critical existential thinking and transcendental awareness can predict increase of social desirability among students.

\section{Conclusion and discussion}

The results of the first hypothesis showed that there is a significant relationship between social desirability and all constructs of spiritual intelligence and total spiritual intelligence of students. These results are consistent with those of $[6,17,18]$ and yet they are inconsistent with those of [19]. Social desirability is the manner of interacting with people in different emotional situations and using this indicator to create an effective relationship with them. This feature requires the ability to recognize, differentiate, and control emotions in different situations. Therefore, these features among students have led them to use their spiritual intelligence, which naturally leads to success and control of their emotions in their school environment.

The results of the second hypothesis showed that there is a significant relationship between all components of spiritual intelligence, total spiritual intelligence and students' academic achievement. These results are consistent with those of $[13,14,20,21,8,22,23,24]$. It can be said that by teaching each constructs of spiritual intelligence at schools, students' academic achievement can equally increase. One of the constructs of emotional intelligence is critical existential thinking, when students have critical thinking, they refuse to accept anything blindly and try to think and contemplate about learning subjects, and thinking about the issues is conducive to their solution. Eventually, they can make progress in their education. The next construct of spiritual intelligence is personal meaning production. This construct is very effective in determining the overall goals of life. These general objectives can determine the directions of detailed life dimensions. When a person's life takes on meaning, his motives are manipulated and work in line with this meaning. As a result, this general flow of students' academic motivation is also encouraged, leading to academic achievement. Another construct is awareness. Evidence has shown that learning weakness and performance decline in many students are due to lack of attention, concentration and insensitivity to environmental stimuli. Another construct is self-awareness; when students are aware of their strengths and weaknesses, they can make more rational decisions in favor of their educational progress, and these prudent decisions will build up their academic achievement. The results of the third hypothesis showed that there is a significant relationship between social desirability and students' academic achievement. These results are consistent with those of [12,25,]. however, those of [26] were different. Students with high societal desirability have better communication with other students, so that they can compensate for 
their weaknesses and contribute to their academic achievement.

The results of the fourth hypothesis showed that critical existential thinking and transcendental awareness are positively and significantly linked with social desirability. According to studies conducted by the researcher, no similar research has ever been done with this research question. Considering that the results indicate a positive and significant relationship between social desirability and spiritual intelligence, and spiritual intelligence and academic achievement, the following suggestions are presented to increase students' academic achievement: 1. provide courses for increasing social desirability and emotional intelligence and their impact on academic achievement of students; 2 . identify practical ways of using the constructs of spiritual intelligence among students; for the limitations of this research, we can refer to research carried out in this area, time consuming process of data collection, and inaccuracy of questionnaire information filled by students.

\section{References:}

1. Seif, A. (2009). Modern educational psychology, 6th ed., Duran Publishing.

2. Peterson, C.H., Casillas, A., \& Robbins, S.B.(2006). The student readiness inventory and the big five: examining social desirability and college academic performance. Personality and Individual Differences, 41(4), 663-673.

3. taghavi,M.R\&Baba nazari,L.(2006). Study of the desirability of male and female students of engineering and human sciences of Shira university. Third International Student Mental Health Seminar, University of Science and Technology,78-80.

4. Vaughan,F.(2003).WHAT IS SPRITUAL INTELEGENCE?journal of humanistic psychology.42,(2).

5. Qasemi, H. Rezaee, M. and Eshraghi (2015). Relationship between spiritual intelligence and volunteer motivation in education association. Vol. 31, issue 34, pp. 139-158

6. Tawata, R. (2016). Relationship between spiritual intelligence and social desirability among female college students in public schools of Maneh and Samalghan counties. 6th International Conference on Psychology and Social Science, Tehran, Mehr-Eshragh Hamayeshgaran,

https://www.civilica.com/Paper-RAFCON06RAFCON06_046.html

7. Armanfar, H. (2015). Relationship of Social Desirability and Irrational Beliefs to Academic Performance of Sama Technical and Vocational Students at Kazeroon Branch. Master's thesis, Shiraz, Islamic Azad University, Marvdasht Branch, Faculty of Educational Sciences and Psychology.

8. Motaharinejad, H. Shokohi, V. and Khademipour, F. (2015). Investigating the relationship between spiritual intelligence and academic achievement among primary school students of Erzoieh County. National Conference on Psychology of Social Sciences and Education, Mazandaran. Kumeh Research Scientific Institution, Elm Avaran Danesh, https://www.civilica.com/Paper-SEPP01SEPP01_083.html

9. Mokfi, V. (2013). Relationship of spiritual intelligence and academic performance to academic achievement of male high school students in Minab County. Master's thesis., Shiraz, Islamic Azad University, Marvdasht Branch, Faculty of Educational Sciences and Psychology.

10. Molazadeh, A. Gholami, M. Hamayeli, H. Mortazavi, A. Dolatkhah, H. Darvishi, A. and Ghodsi, R. (2013). Journal of Social Health. Vol. 7, issue 2, series No. 16, pp. 56-64

11. Raisi, M. Ahmari, H. Heidari, S. Jaafarboglou, E. Abedini, Z. and Batahi, A. (2013). Relationship of spiritual intelligence to happiness and academic achievement among Students of Qom University of Medical Sciences. Journal of Medical Education, Vol. 13, Number 5. PP. 431-440.

12. Abulghasemi, A. and Javanmiri, L. (2012). Role of social desirability, mental health, and self-efficacy in predicting education progress of female students. Journal of School Psychology, vol. 1, issue 2, pp. 6-20 .

13. Patel,s,.Ghani,A.(2016). "A Relationship between Spiritual Intelligence and Emotional Intelligence of Higher Secondary students in relation to Academic Achievement".bRdU.international Journal Of multidisciplinary, Volume-1,Issue-IX,67-72.

14. Arbabisarjou, A(2013). Relation between emotional intelligence,spiritual intelligence, and 


\begin{tabular}{l|lr|ll|ll} 
& ISRA (India) & $=\mathbf{1 . 3 4 4}$ & SIS (USA) & $=\mathbf{0 . 9 1 2}$ & ICV (Poland) & $=\mathbf{6 . 6 3 0}$ \\
Impact Factor: & ISI (Dubai, UAE) $=\mathbf{0 . 8 2 9}$ & PUHЦ (Russia) $=\mathbf{0 . 2 0 7}$ & PIF (India) & $=\mathbf{1 . 9 4 0}$ \\
& GIF (Australia) & $\mathbf{0 . 5 6 4}$ & ESJI (KZ) & $=4.102$ & IBI (India) & $=\mathbf{4 . 2 6 0}$ \\
& JIF & $=\mathbf{1 . 5 0 0}$ & SJIF (Morocco) & $=\mathbf{2 . 0 3 1}$ & & \\
\hline
\end{tabular}

students' academic achievement. Conference: World of Science Journal, Volume: 1(8).

15. Yazici,H., Seyis.S and Altun,F.(2011). Emotional intelligence and self-efficacy beliefs as predictors of academic achievement among high school students. Procedia Social and Behavioral Sciences 15, 2319-2323.

16. Teri Michel,s(2008). Social desirability and perceived competence related to academic achievement: Gender and ethnicity differences. ILLINOIS INSTITUTE OF TECHNOLOGY.

17. Farahangpour, F. Khadivi, A. and Adib, Y. (2010). Relationship of spiritual intelligence and self-esteem to academic achievement of students in the academic year 2010-2011. Journal of women and household studies. Vol. 3 , issue 9 , pp. $99-122$

18. Kluemper,D.(2008). Trait emotional intelligence: The impact of core-self evaluations and social desirability. Personality and Individual DifferencesVolume 44, Issue 6, Pages 1402-1412.

19. Aitken Schermer,J.,Vernon,P.(2010). The correlation between general intelligence $(\mathrm{g})$, a general factor of personality (GFP), and social desirability. Personality and Individual Differences, Volume 48, Issue 2, Pages 187189.

20. Mozaffari Makki Abadi,M,. Tabbodi,M and, Rahgozar,H(2013). The Relationship between Spiritual Well-Being and Academic Achievement. European Online Journal of Natural and Social Sciences 2013; European Online Journal of Natural and Social Sciences; www.european-science.com Vol.2, No.3 Special Issue on Accounting and Management.
21. Mansouri, R. Al Behbahani, M. Esmaeili, Z. and Amjadian, F. (2016). Effectiveness of teaching spiritual intelligence constructs on academic achievement of high school students. Education Development of Jundee Shapour University, Journal of Center for Studies and Development of Medical Sciences Education, Special Issue 95

22. Omidvar, S. Ghermezi, Kh. Azhdari, A. and Omidvar, A. (2015). Relationship of spiritual intelligence and self-regulatory to academic performance of students. Journal of Psychology Studies and Educational Sciences https://www.civilica.com/Paper-JR_JRPEJR_JRPE-1-1_001.html

23. Erdogdu, M.Y. \& Kenarh,Õ. (2008). Duygusal zeka ile akademik baúarÕarasÕndaki iliúki (The relationship emotional intelligence and academic achievement). Milli Eitim Dergisi, 178, 297-310.

24. Parker, J. D.A. et al. (2004). Academic achievement in high school: does emotional intelligence matter? Personality and Individual Differences,37, 1321-1330.

25. Darnon, C., Dompnier, B., Delmas, F., Pulfrey, C., \& Butera, F.(2009). Achievement Goal Promotion at University: Social Desirability and Social Utility of Mastery and Performance Goals. Journal of Personality and Social Psychology, 96(1), 119-134.

26. Huang,C(2013). Relation between self-esteem and socially desirable responding and the role of socially desirable responding in the relation between self-esteem and performance. Volume 28, Issue 3, pp 663-683. 